\title{
Green School Grounds as Sites for Outdoor Learning: Barriers and Opportunities
}

\author{
Janet E. Dyment \\ University of Tasmania, Faculty of Education, Launceston, Tasmania \\ 7250, Australia
}

In their review of evidence-based research entitled A Review of Research on Outdoor Learning, Rickinson et al. (2004) identify five key constraints that limit the amount of outdoor learning. This paper explores whether green school grounds might be a location where these constraints could be minimised. Specifically, it reports on a study that sought to investigate the use of green school grounds as sites for outdoor learning, to identify barriers that impede such use, and to examine how these barriers differ from those cited in Rickinson et al.'s review. A mixed method approach was used: (1) 149 questionnaires were completed by administrators, teachers, and parents associated with 45 school ground greening initiatives in a Canadian school board; (2) 21 follow-up interviews were completed at five of the schools. Study participants reported that green school grounds are used regularly for teaching some subjects, notably science and physical education, but considerably less for teaching language arts, mathematics, and geography. They also identified a series of barriers that limit the amount of outdoor learning and these are compared to those identified by Rickinson et al. (2004). This paper concludes with a discussion of how the opportunities for teaching and learning on green school grounds can be more fully maximised.

Keywords: school ground greening, teaching, outdoor classrooms, outdoor learning, environmental education, barriers

\section{Introduction}

While the concept of 'outdoor learning' is a broad and complex one, with endless permutations of foci, outcomes, and location (see Rickinson et al., 2004: 15; Scott \& Gough, 2003: 54), an emerging body of evidence-based research in environmental education points to its benefits. A recent review by Rickinson et al. (2004) points to the particular cognitive, affective, interpersonal/social, and physical/behavioural impacts of outdoor learning that are occurring through three kinds of outdoor learning activities: (1) fieldwork and outdoor visits; (2) outdoor adventure education; and (3) school grounds and community projects.

The benefits of outdoor learning are broad-reaching to students, teachers, and the wider community: for example, students who have had opportunities to engage in outdoor learning have demonstrated an increased ability to think creatively and critically and an improved performance on standardised tests, teachers have reported renewed enthusiasm for learning, and the community has benefited from having students who are active and engaged critical citizens (Ballantyne \& Packer, 2002; Lieberman \& Hoody, 1998; Rickinson et al., 2004). 
Paralleling the growing understanding of the positive impacts of outdoor learning is a growing realisation that many opportunities for outdoor learning for school students has decreased substantially in recent years (e.g. Barker et al., 2003; Fisher, 2001; Puk \& Behm, 2003). The titles of recent investigations tell a troubling story. A report published by the UK-based Field Studies Council and British Ecological Society (Barker et al., 2003) explores if teaching biology through fieldwork is 'heading for extinction' and Fisher (2001) documents the 'demise of fieldwork' in science education in the United Kingdom. Puk and Behm (2003) point to the 'diluted curriculum' in Canada that has removed environmental science (which is well suited for outdoor learning) as a teaching subject.

Many researchers have documented numerous institutional, cultural, and logistical barriers that have limited the amount and nature of outdoor learning (e.g. Barker et al., 2003; Comishan et al., 2004; Fisher, 2001; Ham \& Sewing, 1988; Hart \& Nolan, 1999; McCutcheon \& Swanson, 2001; Rickinson et al., 2004; Simmons, 1998). Rickinson et al. (2004), in their review of the literature on outdoor learning, summarise five key barriers to outdoor learning:

(1) Fear and concern about young people's health and safety (e.g. issues around liability).

(2) Teacher's confidence and expertise in teaching and learning outdoors (e.g. lack of pre- and in-service training for teachers).

(3) The requirements of school curricula (e.g. mandated curriculum leaves little room for outdoor learning, not enough time to undertake outdoor learning, standardised testing makes it difficult to assess outdoor learning, outdoor learning is only incorporated into subjects such as science).

(4) Shortages of time, resources and support (e.g. too much extra work for teachers, lack of funding, transportation complications).

(5) Wider changes within the education sector and beyond (e.g. larger class sizes, institution-wide timetables limit opportunities for field work, emphasis on back to basics).

As these conflicting understandings as to the benefits of and limitations to outdoor learning emerge simultaneously, I have become increasingly interested in understanding if and how green school grounds might be particularly well suited locations to facilitate outdoor learning. Clearly one would expect that some of the barriers cited by Rickinson et al. (2004) are unique to certain locations, such as field centres, that require students to travel from the school, often at considerable expense. Might, then, some of the barriers to outdoor learning be mitigated on green school grounds? For example, might commonly cited barriers to outdoor learning, such as transportation complications, cost and liability concerns, be non-issues on school grounds? If this is the case, then perhaps green school grounds are particularly well situated to facilitate outdoor learning.

This paper draws on research conducted on green school grounds in a school board in Canada and it reports on a study concerned with three main objectives: (1) to explore if and how green school grounds are being used as sites for outdoor learning; (2) to identify barriers that impede instruction on green school grounds; and (3) to explore if and how these barriers differ from those cited in Rickinson et al.'s (2004) Review of Research on Outdoor Learning. I first turn to a brief 
review of some of the literature that points to the potential of school ground greening initiatives as sites for outdoor learning.

\section{Green(ing) School Grounds as Sites for Outdoor Learning}

The potential role of green school grounds to facilitate formal, informal, and non-formal outdoor learning experiences is fairly well established (Dyment, 2005; Titman, 1994, 1999). In terms of the formal curriculum, examples from the literature suggest that numerous subjects/topics can be taught on green school grounds, including reading, writing, mathematics, science, art, environmental education, health, drama and social studies (Adams, 1990; Bell, 2001b; Centre for Ecoliteracy, 1999; Cronin-Jones, 2000; Engel, 1991; Gamson Danks, 2000; Grant \& Littlejohn, 2001; Hansen-Moller \& Taylor, 1991; Lieberman \& Hoody, 1998; Malone \& Tranter, 2003b; Olwig, 1991; Rhydden-Evans, 1993; Thomson \& Arlidge, 2000).

The general cognitive benefits of outdoor learning on a school ground are well understood and quite similar to the documented benefits of learning in other locations, such as field centres, camps, or zoos (e.g. Alexander et al., 1995; Bell, 2001b; Canaris, 1995; Eden, 1998; Konoshima, 1995; Mabie \& Baker, 1996; Moore \& Wong, 1997; Rahm, 2002; Rickinson et al., 2003). Researchers who have investigated the potential of green school grounds as outdoor classrooms generally agree that when the context for learning changes from an indoor, book-centred environment to an outdoors and nature-centred environment, students find it to be a more meaningful context for education. Learning easily comes alive, as students are able to handle, touch, smell, and even taste the materials they are learning with and from. Outdoor learning on green school grounds can help to motivate and inspire students who do not learn best in classroom. Learning is also enhanced because green school grounds provide endless opportunities for learning about interconnections. For example, instead of seeing subjects as discreet entities, students experience first hand the interconnections between subjects, like maths, language arts, and science, as skills are often required from many subjects to complete a task in the outdoor classroom. Students also get opportunities to see the interconnections between their education, their home lives, their environment, and their future.

Other researchers point to the informal learning that can occur on a green school ground (Adams, 1993; Moore \& Wong, 1997; Titman, 1994). Informal learning is intrinsically motivated learning that happens without teacher intervention. It occurs when students have unstructured time on the green school ground and they learn social and behavioural skills (Adams, 1993).

Some researchers have identified the unique learning opportunities that green school grounds afford, as compared to other more geographically novel environments (Dyment, 2004b; Martil-de Castro, 1999). Martil-de Castro (1999) notes that some of the characteristics of the urban environment, which she thought would inhibit opportunities for outdoor learning, actually ' proved to be the most beneficial and useful' (p. 15). She found that the lack of visible biological diversity, the presence of urban infrastructure, and the presence of urban poor allowed an opportunity to bring issues of social equity into her lessons on outdoor learning. She was able to make links with class, race, and gender in her environmental education lessons. 
Until recently, much of the literature provided only qualitative or anecdotal evidence in support of the advantages of formal and informal learning on the school grounds (e.g. Adams, 1991, 1993; Moore \& Wong, 1997; Titman, 1994). While many of these benefits are laudable, they are also difficult to measure. Given that so much emphasis in educational circles is placed on academic performance, as measured by standardised tests, many wondered if there was a link between school ground learning and academic performance. Until recently, there was a lack of literature that quantitatively explored a relationship between outdoor learning on school grounds and students' learning outcomes. Recent studies, however, have generated quantitative evidence that does lend some support for the potential educational benefits of formal instruction in environments such as school grounds (Lieberman \& Hoody, 1998; Simone, 2002). ${ }^{1}$

Of course, learning happens not only through formal instruction on the green school ground. A growing body of research points to the benefits of student involvement in the process of greening the ground (Dyment, 2004a; Hart, 1997; Hunter et al., 1998; Kenny, 1996; Moore \& Wong, 1997; Titman, 1994). This research argues that a democratisation process is one of the most important aspects of children's participation in school ground greening projects, more important perhaps even than the particular impacts of any of their projects.

In addition to the outdoor learning benefits, when a school ground is greened, there are numerous other benefits for students, teachers, the surrounding community and the environment. For example, recent research appears to indicate that students attending greened schools benefit from increased play opportunities (Malone \& Tranter, 2003b; Moore, 1996), safer and less hostile outdoor environments (Cheskey, 1994; Evans, 1995), increased connections to the natural environment (Bell, 2001a; Nabhan \& Trimble, 1994), more inclusive environments (Mannion, 2003; Titman, 1994) and healthier environments (Toronto District School Board, 2004). Teachers working at schools that have been greened report unique opportunities for curriculum development (Moore \& Wong, 1997) and reduced classroom management problems (Lieberman \& Hoody, 1998).

Not surprisingly, given the reported positive impacts, there has been a growing number of not-for-profit organisations that facilitate the process of school ground greening. Organisations such as Evergreen in Canada, the Centre for Ecoliteracy in the United States, Learning Through Landscapes in the United Kingdom, Movium in Sweden, EcoSchools in numerous countries, as well as the Gould League and Learnscapes in Australia continue to grow in their profile and scope. ${ }^{2}$ Many of these organisations also provide assistance for teachers who want to use green school grounds as outdoor classrooms, through the development of curricular resource material (e.g. Department of Education and Skills, 2003; Evergreen, 2001).

\section{Methods}

The study sites were selected in an urban school board in southern Ontario, Canada, which has 451 elementary schools and 102 high schools. The school board is located in a city that is diverse in terms of ethnic composition and socioeconomic status of students attending these schools. The school board was selected because of the large number of schools with greening initiatives 
(approximately 20\% of schools in the board). The projects were at various stages of their greening process. With a view to understanding if and how outdoor learning is happening on green school grounds, two research tools were used: questionnaires and interviews.

\section{Questionnaires}

A research package, containing four questionnaires, was distributed to each principal at 100 schools with green school grounds in the school board. ${ }^{3}$ In addition to completing their own questionnaire, each principal was asked to distribute the remaining questionnaires to the following three respondents: (1) an involved teacher assuming a leadership role in greening or maintaining the school ground, (2) a teacher who is not involved in the process of greening the school ground, as well as (3) a parent who has been involved in the greening project. In order to assist the principal in their selection of the additional respondents, I provided descriptive criteria for each respondent. ${ }^{4}$ A total of 400 questionnaires were distributed (four questionnaires at 100 schools).

On the questionnaire, respondents were asked to reflect on if and how the green school ground was used to deliver curricular material related to language arts, mathematics, physical education, geography, and science. Standard demographic information was also collected. All questionnaires were numerically coded to ensure confidentiality.

\section{Case study interviews}

With a view to having a greater understanding of if and how teaching occurred on the green school ground, follow-up case studies were done at five schools. The schools were randomly selected from the returned packages of questionnaires to include one school from each 'category' of socioeconomic statuses (i.e. very high, high, medium, low, very low).

Individual interviews were conducted with the three individuals who completed the questionnaires: the involved teacher, the principal, and the parent. ${ }^{5}$ The interviews were taped and lasted between 30 and 60 minutes depending on how much information the participant had to offer. The semistructured interview consisted of a series of open and closed questions that explored curriculum delivery, teaching, and outdoor learning on the green school ground.

\section{Data analysis}

The questionnaire responses were analysed using SPSS. Descriptive statistics were generated to understand respondent demographics and their perceptions of outdoor learning on the green school ground.

Data from the interviews were fully transcribed. I read through the transcriptions with a view to identifying potential themes and topics that were relevant to the research objectives. I used ATLAS.ti 4.1. (Visual Qualitative Data Analysis, Management and Theory Building) to code the interview transcriptions and develop conceptual themes that allowed me to fully understand teachers', administrators', and parents' perceptions of the green school ground as an outdoor classroom. 


\section{Response Rates and Demographics}

\section{Questionnaire response rates, school and respondent profiles}

Out of the 100 schools invited to participate, 45 returned at least one questionnaire ( $45 \%$ response rate at the school level) (Table 1). Approximately half the schools returned all four questionnaires, whereas 32\%, 11\%, and $7 \%$ returned three, two and one questionnaire(s) respectively. At the individual questionnaire level, 149 out of a possible 400 questionnaires were returned (37\% response rate at the questionnaire level). Forty-one principals, 39 involved teachers, 36 uninvolved teachers, and 33 parents completed questionnaires. The majority of respondents were women (83\%).

Table 1 Profile of 149 questionnaire respondents

\begin{tabular}{|c|c|c|}
\hline Characteristic and variable & Frequency & Percentage \\
\hline \begin{tabular}{|l|} 
Role \\
Principal \\
Involved teacher \\
Uninvolved teacher \\
Parent \\
\end{tabular} & $\begin{array}{l}41 \\
39 \\
36 \\
33 \\
\end{array}$ & $\begin{array}{l}27.5 \\
26.2 \\
24.2 \\
22.1 \\
\end{array}$ \\
\hline $\begin{array}{l}\text { Gender } \\
\text { Male } \\
\text { Female } \\
\end{array}$ & $\begin{array}{r}26 \\
123\end{array}$ & $\begin{array}{l}17.4 \\
82.6\end{array}$ \\
\hline $\begin{array}{l}\text { Age } \\
20-29 \\
30-39 \\
40-49 \\
50-65\end{array}$ & $\begin{array}{r}7 \\
40 \\
56 \\
46 \\
\end{array}$ & $\begin{array}{r}4.7 \\
26.8 \\
37.6 \\
30.9 \\
\end{array}$ \\
\hline $\begin{array}{l}\text { Highest level of education completed } \\
\text { College diploma } \\
\text { Undergraduate } \\
\text { Masters } \\
\text { Doctorate } \\
\text { Other } \\
\end{array}$ & $\begin{array}{r}23 \\
73 \\
36 \\
2 \\
15\end{array}$ & $\begin{array}{r}15.4 \\
49.0 \\
24.2 \\
1.3 \\
10.1\end{array}$ \\
\hline $\begin{array}{l}\text { Years working in public/private education system * } \\
0-2 \\
3-5 \\
6-10 \\
11-20 \\
\text { More than } 20 \\
\end{array}$ & $\begin{array}{r}4 \\
8 \\
12 \\
36 \\
56\end{array}$ & $\begin{array}{r}3.4 \\
6.9 \\
10.3 \\
31.1 \\
48.3 \\
\end{array}$ \\
\hline $\begin{array}{l}\text { Number of years involved with school ground greening projects } \\
0 \\
1-2 \\
3-5 \\
6-10 \\
11-20 \\
\text { More than } 20\end{array}$ & $\begin{array}{r}31 \\
20 \\
54 \\
32 \\
11 \\
1\end{array}$ & $\begin{array}{r}20.8 \\
13.4 \\
36.2 \\
21.5 \\
7.4 \\
0.7\end{array}$ \\
\hline
\end{tabular}

Note: $N=149$ respondents

* Responses from administrators, involved teachers and uninvolved teachers only $(n=$ 116). 
Table 2 Profile of 45 schools from questionnaires

\begin{tabular}{|c|c|c|}
\hline Characteristic and variable & Frequency & Percentage \\
\hline $\begin{array}{l}\text { Level of school } \\
\text { Elementary (Kindergarten to Grade 5/6) } \\
\text { Middle (Grade 5/6-Grade 8) } \\
\text { Secondary (Grade 9-Grade 12) }\end{array}$ & $\begin{array}{r}32 \\
6 \\
7\end{array}$ & $\begin{array}{l}71.1 \\
13.3 \\
15.6 \\
\end{array}$ \\
\hline $\begin{array}{l}\text { Socioeconomic status of school catchment area* } \\
\text { Very high } \\
\text { High } \\
\text { Medium } \\
\text { Low } \\
\text { Very low }\end{array}$ & $\begin{array}{r}9 \\
11 \\
8 \\
9 \\
8\end{array}$ & $\begin{array}{l}20.0 \\
24.4 \\
17.8 \\
20.0 \\
17.8\end{array}$ \\
\hline $\begin{array}{l}\text { Length of school ground greening project (years) }+ \\
<2 \\
3-5 \\
6-10 \\
>11 \\
\text { Unknown }\end{array}$ & $\begin{array}{r}6 \\
14 \\
14 \\
6 \\
5\end{array}$ & $\begin{array}{l}13.3 \\
31.1 \\
31.1 \\
13.3 \\
11.2\end{array}$ \\
\hline $\begin{array}{l}\text { Number of students } \\
<200 \\
201-500 \\
501-1000 \\
>1000\end{array}$ & $\begin{array}{r}1 \\
26 \\
11 \\
7\end{array}$ & $\begin{array}{r}2.2 \\
57.8 \\
24.4 \\
15.6\end{array}$ \\
\hline $\begin{array}{l}\text { Number of staff } \\
<20 \\
21-40 \\
41-60 \\
>60\end{array}$ & $\begin{array}{r}11 \\
20 \\
7 \\
7\end{array}$ & $\begin{array}{l}24.4 \\
44.4 \\
15.6 \\
15.6\end{array}$ \\
\hline
\end{tabular}

Note: $N=45$ schools

* The socioeconomic status of each school was provided by the school board. It is determined by evaluating school communities as a function of: (1) average and median income of families with school-aged children; (2) parental education; (3) proportion of loneparent families; (4) recent immigration; (5) housing type (apartment, single detached house); and, (6) student mobility.

t Data for this response were sought from the involved teacher. If the involved teacher did not respond, data were used from the parent questionnaire. If neither respondent indicated a response, 'unknown' was recorded.

The majority of the schools participating were elementary (Kindergarten to Grade 6) $(n=31)$, as well a number of middle schools (Grade 6-8, $n=6)$ and high schools (Grade $9-12, n=7$ ). The schools represented a range of socioeconomic statuses (Table 2). Additional demographics for both respondents and the schools are found in Table 1 and Table 2 respectively.

\section{Follow-up case study school and interviewee profiles}

The five elementary schools ${ }^{6}$ (Grades K-6) were located in areas of differing socioeconomic statuses, ranging from very low to very high. The schools ranged in terms of the number of children (280-950 students) as well as their staff team (13-48 staff). 
I interviewed a total of 21 individuals during Phase 2 of the research project (four principals, seven teachers, 10 parents). A large majority of interview respondents were women $(81 \%)$. The teachers and principals involved in the follow up case study had been involved in the educational system for a minimum of eight years and a maximum of 34 years, and had been working at their current schools between two and 15 years. The interviewees had been involved in greening projects for a varied amount of time: one respondent had only been involved one year, while another had been involved for 12 years.

\section{Results}

\section{Are green school grounds being used for outdoor learning?}

Questionnaire respondents were asked to indicate how often the green school ground is used as an outdoor classroom for instructing five subjects. They indicated that green school grounds are used most often to teach physical education (76\% of respondents) and science $(79 \%)$, two subjects that are readily associated with the outdoors (Table 3). Language arts, mathematics, and geography are taught less frequently on the green school ground, with $41 \%, 53 \%$ and $46 \%$ of questionnaire respondents indicating that these respective subjects are taught 'never/rarely'. Study participants commented that the green school ground is used to teach other subjects not listed on the questionnaire, such as art and drama, illustrating the potential to integrate these spaces widely across the curriculum.

The questionnaire respondents were also asked to indicate what percentage of the teachers at the school use the green school ground as an outdoor classroom. More than $50 \%$ of respondents reported that less than $10 \%$ of the teachers at their school take lessons on the green school ground (Table 4).

I was able to gather a richer and more textured understanding of how green school grounds are being used as outdoor classrooms when I performed my five

Table 3 Perceptions of respondents

\begin{tabular}{||l|c|c|c|c||}
\hline \multirow{2}{*}{} & \multicolumn{3}{|c|}{ Percentage of respondents reporting } \\
\cline { 2 - 5 } & $\mathbf{N}$ & $\begin{array}{c}\text { Never/ } \\
\text { rarely }\end{array}$ & Sometimes & $\begin{array}{c}\text { Often/ } \\
\text { regularly }\end{array}$ \\
\hline I use our school ground to help me instruct & & & & \\
curricular material related to: & & & & \\
(1) Language arts & 127 & 41 & 39 & 20 \\
(2) Mathematics & 125 & 53 & 36 & 12 \\
(3) Physical education & 130 & 24 & 29 & 47 \\
(4) Geography & 128 & 46 & 32 & 22 \\
(5) Science & 134 & 21 & 32 & 47 \\
\hline \hline
\end{tabular}

Note: The wording included in this table represents the exact wording found on the involved teacher's survey. Slight changes were made among the four different questionnaires to ensure that each question was relevant to each respondent. For example, the header to these questions on the principal questionnaire reads 'Teachers at my school use the school ground to help them instruct curricular material related to:' and the parent questionnaire reads 'Teachers use the school ground to help them instruct curricular material related to:'. 
Table 4 Percentage of teachers that instruct on green school grounds

\begin{tabular}{|c|c|c|}
\hline Percentage of teachers & Number of schools & Percentage of schools \\
\hline 0 & 5 & 13.9 \\
\hline $1-10$ & 14 & 38.9 \\
\hline $11-20$ & 4 & 11.1 \\
\hline $21-50$ & 7 & 19.4 \\
\hline$>50$ & 6 & 16.7 \\
\hline
\end{tabular}

Note: $N=45$ schools

* Nine schools did not respond to this question.

follow-up case studies. Not surprisingly, the amount of teaching occurring on the green school grounds varied among the five schools and was influenced by numerous factors. At a small number of schools, it appears that a considerable amount of teaching does happen on the green school ground. At School B, for example, enthusiasm for teaching on the school ground is high and teachers are encouraged to use the 'outdoor classroom' for teaching a variety of subjects. In the following quotation, the principal at School B described how some teachers at her school are using the school ground in this way:

Our grade 1's have just finished a unit on bugs. Four years ago we didn't have any bugs in our school yard. Now we have a ton of bugs. In fact our trees were totally covered with ladybugs for about a week, and a whole different variety of types of ladybugs which is quite exciting. I didn't know that there were that many different types of ladybugs until they went out there. And they had their magnifying jars, and their reading buddies who are the older students, who were their science buddies for that day ... they went out looking for bugs and they found all kinds of wonderful bugs. So there's a very simple example.

At points in time during School D's greening project, a lot of outdoor learning occurred in the school ground as well. In the mid-1990s, a teacher's aid was hired for nine hours a week and her sole responsibility was to provide instruction in the garden. She described how much informal learning happened through the maintenance of the garden:

Teaching just happened out there ... we picked up apples and leaves and put them in the composter. We screened compost. We brought mulch in and soil in, and the older children spread it on the hillside. We planted. And I did a lot by letting them learn through playing. . . . They would dig deep holes in them, build landscapes, whatever. Stomp through puddles.

While enthusiastic about the benefits, study participants also commented extensively on the untapped potential of the greening initiatives as outdoor classrooms. They were anxious to see much more of the curriculum delivered outdoors and in fact expressed a keen disappointment at the relatively small percentage of teachers who were using the green school grounds. In the words of 
one parent: ' ... curriculum is the biggest area in which we have failed ... teachers seem to prefer traditional indoor teaching and there has been very poor participation by teachers' (Parent, School A). This sentiment was echoed at all the schools where follow-up interviews occurred: 'I would say probably not as many teachers use it as they should or could' (Teacher, School A); 'Probably at the beginning there were more teachers involved and slowly it's become less, unfortunately' (Teacher, School C); 'It is rarely used for teaching any more' (Teacher, School D); and, 'They are using it, although not enough' (Teacher, School E). This sentiment was even echoed by interviewees at School B, where a considerable amount of teaching actually is happening: 'Potential for teaching is not being realised for sure' (Parent, School B) and, 'There could always be more' (Principal, School B).

To summarise, many study participants believed that the green school grounds are not used nearly as much as they might be for an outdoor classroom. They reported that many subjects are not being taught with regularity on the green school ground. It thus appears that much room exists to enhance the teaching that is occurring on the green school grounds in this study.

\section{What are the barriers to using green school grounds as outdoor classrooms?}

Study participants identified many barriers that limited the amount of outdoor learning happening on the green school grounds. I now turn to a presentation of these barriers, using Rickinson et al.'s (2004) categorisation of 'barriers to outdoor learning'.

\section{Fear and concern about young people's health and safety}

Rickinson et al. (2004) identified that a major barrier to outdoor learning was concerns about young people's health and safety. On the green school grounds profiled in this study, this was not identified as a major barrier. While study participants were aware of health and safety issues on green school ground (e.g. allergic reactions to vegetation or insects, injuries from natural elements, reduction in sight lines from trees, concerns about water safety around aquatic elements), the large majority were not overly worried about them, and expressed a willingness to accept and / or manage these risks. For example, they described how compost bins could be strategically situated to reduce risk of bee stings and how trees could be planted to ensure that sight lines are not compromised.

Teacher's confidence and expertise in teaching and learning outdoors

A major barrier to outdoor learning that emerged in this study, as well as in Rickinson et al.'s (2004) review, was that many teachers lacked the confidence or skills about how to use the green school ground as an outdoor classroom. Many participants suspected that teachers might find it difficult to even imagine teaching outside, if all of their own education (as a student in primary, secondary, tertiary, and teacher training) and subsequent career in teaching has occurred in traditional indoor classrooms. As one parent explained, 'it's not always obvious how to use these spaces, especially when you have a standard routine and you've always taught in a classroom' (School B). Participants suspected that many teachers were 'bound' in traditional indoors views of 
learning, and found it difficult to imagine breaking out of their patterns. To illustrate, one parent indicated, 'When you get caught in your little square boxes, you stay in your little square boxes' (School B) and another teacher agreed 'It's just easier and safer maybe to teach the old way in the classroom' (School A).

In terms of teacher confidence, many participants indicated that teachers were concerned about losing control in an outdoor classroom. They noted that classrooms offer familiarity and security, important considerations when one is responsible for so many students. In the words of one teacher, 'Outside it's an open area, it's not a classroom, there's less control with your students ... because obviously outside it's a different place ... so it is harder to teach in that environment. So maybe some people are hesitant to teach out there' (School C).

As some study participants suggested, however, the challenge lies much deeper: teachers are often limited by conventional assumptions about education - about their own need to 'master' the subject area, to have all the answers prepared in advance, and to address first and foremost the 'minds' of their students. Such assumptions sit uneasily with the realities of outdoor learning where the environment is less easy to control, where learning outcomes are less predictable and not necessarily measurable, and where learning experiences are more fully embodied.

The large majority of study participants emphasised the need for teacher training to provide teachers with the confidence and skills to take students outside on the green school ground.

\section{The requirements of school curricula}

Rickinson et al. (2004), in their review of the research on outdoor learning, indicated that curriculum constraints are a major barrier to outdoor learning. Participants in this study also identified this constraint, with many asserting that the mandated curriculum does not explicitly endorse or support the use of school grounds for curriculum delivery. They stated that the curriculum requires that the majority of teaching and learning in their schools takes place within the classroom.

Several participants indicated that certain subject areas or grade levels lent themselves more easily to using the green school grounds as an outdoor classroom. Where mandated curriculum links were most obvious, for instance in science, teachers were more likely to take students outside. Yet study participants indicated that, too often, little teaching is happening beyond these obvious subjects: 'Some teachers think "This is math time, I can't go outside" and they might not see the benefits of it' (Teacher, School C) and 'Some people think that the only thing you can teach outside is science ... they don't realise that there are probably 3000 places in that elementary curriculum that we could be out there doing stuff' (Teacher, School A). This lack of obvious curricular links is a key barrier that limits outdoor learning.

Study participants also maintained that province-wide standardised testing has tended to reinforce this classroom-based orientation towards the curriculum. Schools appear to be placing increased emphasis on literacy and numeracy, with a view to 'teaching to the tests' (Teacher, School E). This often can leave little room for outdoor teaching: 'Teachers who focus on the three Rs 
are going to be resistant in using the outdoor classroom ... fearing it will take away from the most important teachings that will be tested' (Questionnaire respondent). Thus the potential to use school grounds as an outdoor classroom remains largely unrecognised and untapped.

Importantly, study participants stressed the need for curriculum packages to help teach (and to help justify teaching) in the outdoor classroom across the curriculum. In the words of one parent: 'If they don't get a package that's basically streamlined and simple and tied into the curriculum they're not going to take them into the garden for that specific reason' (School C).

\section{Shortages of time, resources and support}

Unlike Rickinson et al.'s (2004) review that identified time, resources, and support as being key barriers to outdoor learning, the majority of participants in this study reported the opposite and stressed that these factors were key enablers. Compared to outdoor learning that occurs off-site from the school that often requires significant logistical efforts on the part of the teacher (e.g. to reserve a bus, to collect student fees, to secure additional helpers, etc.), participants reported that outdoor learning on green school grounds was comparably easy. They noted that there were few financial costs, few time constraints, and additional support was often not necessary. A principal illustrates: 'Before you'd have to shove them on a bus, send them to a conservation centre, or maybe walk down into the park which is tougher to do with short-legged Grade Ones. But now all they have to do is go out the back' (School B).

\section{Wider changes within the education sector and beyond}

Like Rickinson et al.'s (2004) review, study participants noted additional barriers outside of the immediate school that restricted using the school ground as an outdoor classroom. Some suggested that unrest in the workplace (e.g. strikes, work to rule) had unsettled the teachers, making it difficult for them to get involved in innovative teaching practices: 'Last year, we had labour unrest and had restrictions ... work to rule ... so we had restrictions on what we could and couldn't do during the day' (Teacher, School E). Another teacher agreed, adding 'There's been a war between the teachers and the Board of Education and the Government. And when you're in a state of war there isn't room for extras' (School D). Other study participants, with a long history in educational circles, speculated that school ground greening was yet another educational reform/fad and were resistant to try teaching outside: 'Like many teachers, I have reached my saturation point for new initiatives!' (Questionnaire respondent). Still others indicated that they felt totally overwhelmed with the increasing number of roles and responsibilities that teachers are expected to assume:

They keep piling more responsibilities on to us. Every time we turn around, they say that we have to do this and we have to do that. The teachers are sitting in the staff room saying 'Don't ask me to do a single thing more.' So when you say things [like] 'Can we go clean up the garden?' and 'Why don't you take your math class outside?' they say like, 'What! Now I have to do the garden on top of everything else?' So before it was a fun thing to do and now it's 'Oh my God, more work.' (Teacher, School D) 


\section{Additional barriers}

Participants reported additional barriers to using the outdoor classroom that do not align with the categories of Rickinson et al. (2004), including:

- At some schools, outdoor learning on green school grounds was seen as an add-on to the school programming, and in competition with existing programmes in sports, drama or music. ('You won't be surprised to hear that there are all sorts of other stuff going on in terms of music and we use the swimming pool, etc. So we already have less teaching periods a week ... we're heavily involved in sports and all sorts of things ... dramatic productions ... . we're already too busy to do extra stuff.' Teacher, School A);

- At some schools, poorly designed school grounds limited the amount of outdoor learning that happens. ('We need a space where students can sit down and teachers can actually teach a lesson ... until we have that, there won't be much teaching.' Questionnaire respondent);

- At some schools, teachers reported that they were not supported by their principal to use the outdoor classroom. ('You really need a strong leader to encourage the teachers to go out and use it . . . if your principal doesn't support you, you'll never use it.' Questionnaire respondent); and,

- The Canadian climate makes it difficult to use the outdoor classroom in some seasons. ('It is a great option to leave a non-air-conditioned school and go outdoors in the spring months ... but at $-20^{\circ} \mathrm{C}$, there is no way I am going to bundle my students up for one class.' Questionnaire respondent).

\section{Discussion}

The findings related to the amount and type of teaching occurring on green school grounds point to the untapped potential of these spaces to be used as sites for outdoor learning. Respondents indicated that only a small percentage of teachers were using the green school ground as an outdoor classroom (Table 4). They also indicated that many subjects are rarely being taught on the green school ground: the main subjects being delivered regularly are physical education and science, while language arts, mathematics and geography are taught considerably less often on the green school ground (Table 3). It is difficult to know how 'generalisable' these findings are. Turning to the literature for a frame of reference provides few answers, as there appears to be a range of reports of how school grounds are being used as classroom(s) (from Titman (1999) who found similar findings to this study, to Humphries and Rowe (1994) as well as Moore and Wong (1997) who describe much more use occurring).

Study participants described numerous barriers that limit the use of the green school ground as an outdoor classroom. When I compared the barriers to outdoor learning on school grounds with those identified by Rickinson et al. (2004), there were some similarities and some differences. (Recall that Rickinson et al. (2004) identified these barriers to outdoor learning at a range of locations: (1) fieldwork and outdoor visits; (2) outdoor adventure education; and (3) school grounds and community projects. My study explored barriers only to green school grounds.)

The positive news emerging from this study is that participants consistently noted that two of the barriers identified by Rickinson et al. (2004) were not major 
barriers to teaching on green school grounds. Barrier 1 (concern about young people's health and safety) and Barrier 4 (shortages of time, resources, and support) were not reported to be limiting the amount of teaching occurring on green school grounds. These barriers are thus specific to outdoor learning that occurs in other locations, such as outdoor education centres, where concerns about liability, fund raising, and extra help are real (Barker et al., 2003; Comishan et al., 2004; Fisher, 2001; Simmons, 1998). Clearly there are some advantages and opportunities to having outdoor learning occurring on green school grounds as compared to these other sites.

Yet three of the barriers identified by Rickinson et al. (2004) emerged in this study as well. Study participants indicated that Barrier 2 (teacher confidence and expertise), Barrier 3 (requirements of school curricula), and Barrier 5 (wider changes to education sector) were very present for study participants. For the full potential of outdoor learning on green school grounds to be truly realised, the remaining three barriers must be addressed. This, of course, is no small feat (arguably the two barriers that have been overcome were much easier).

In regards to Barrier 2 (teacher confidence and expertise), as has been noted by others, clearly some training in outdoor learning on green school grounds should be a requirement for pre-service teachers (Scott et al., 2003). This will mean that the teacher training courses must recognise that outdoor learning is an important part of core competencies. This instruction must be delivered to teachers across the curriculum. Training must continue for in-service teachers as well. Perhaps the provision of a short professional development course leading to accreditation in outdoor learning teaching skills could enhance a teacher's employment and promotion prospects (see Fisher, 2001). Of course, external training will do little for those whose internal values and perceptions do not include outdoor learning (see Hart \& Nolan, 1999; Shuman \& Ham, 1997).

Addressing the remaining barriers becomes even more difficult. With respect to Barrier 3 (requirements of school curricula) and Barrier 5 (wider changes to educational sector), in order to fully maximise the potential of green school ground learning, there must be a fundamental shift to recognise that outdoor learning on school grounds is a legitimate form of learning and teaching. As noted by Fisher (2001), these projects will not 'break new ground' unless the potential role of outdoor learning is more fully endorsed . Explicit curricular links that radically enhance the teaching and learning experiences of children at school must occur. Furthermore, educational initiatives such as school ground greening programmes must not stand alone; instead they must be situated within other programmes that work together towards a common vision.

A modest number of additional barriers emerged in this study that did not align neatly with the categories identified by Rickinson et al.'s (2004). Study participants reported that green school grounds were seen as an 'add-on' and 'in competition with' other extracurricular activities, and that outdoor learning was limited by poor designs, unsupportive principals, and bad weather. These barriers also need to be addressed, some of which are relatively easy (e.g. providing assistance to ensure proper design) while others are more complex (e.g. shifting perceptions of green school grounds being 'in competition with' other activities). 


\section{Conclusion}

When a green school ground is not used as an outdoor classroom, important opportunities to maximise the potential are lost. The space is, in effect, left to 'speak for itself' with students making sense by their own accord. There is no shortage of evidence that a green school ground will 'speak for itself', as indicated by the reported impacts on student behaviour (Huttenmoser, 1995; Moore \& Wong, 1997), play (Kirkby, 1989), health (Grahn et al., 1997) and environmental connections (Bell, 2001a; Malone \& Tranter, 2003a, 2003b).

Yet, given the reported additional benefits to using a school ground as an outdoor classroom, it seems a profound loss to have them remain underused. Despite the fact that three of Rickinson et al.'s (2004) barriers emerged in this study, two did not. Given that there are fewer barriers to outdoor learning than for other locations, the full potential of using green school grounds as sites for outdoor learning must be realised.

As long as the barriers identified by Rickinson et al. (2004) exist, efforts must be directed towards removing them. Factors that currently inhibit, impede, and prohibit outdoor learning at all locations (not just green school grounds) must be addressed. In the short term, this task may appear to be daunting; but given the unequivocal benefits of outdoor learning, I suspect the long-term consequences of not addressing them may be even more damaging.

\section{Correspondence}

Any correspondence should be directed to Janet E. Dyment, Centre for Human Movement, Faculty of Education, University of Tasmania, Locked Bag 1346, Launceston, Tasmania, 7250 Australia (Janet.Dyment@utas.edu.au).

\section{Notes}

1. What is noteworthy about these two quantitative studies is their exploration of the relationship between outdoor learning and academic performance across a range of disciplines. Other quantitative studies have explored this relationship for specific subjects, notably environmental science (see Cronin-Jones, 2000; Harvey, 1989).

2. This is just a small list of numerous organisations that are helping to facilitate greening initiatives.

3. This list of schools was generated when the school board was preparing a document related to school ground greening, at which time all schools in the board were asked to indicate if they had a greening project.

4. There are other possible respondents who could have completed the questionnaires. I chose the selected four respondents to investigate a range of perceptions within and outside of the school. Of course, I could have sought perceptions of uninvolved parents, or I could have explicitly delineated between uninvolved and involved principals, but for the purposes of this study, and in the interest of project scale, I chose the selected respondents.

5. In a small number of instances, the original questionnaire respondent was unable to participate in the follow-up interview, in which case I sought input from another individual.

6. The names of all schools have been changed to protect anonymity.

\section{References}

Adams, E. (1990) Learning Through Landscapes: A Report on the Use, Design, Management, and Development of School Grounds. Winchester: Learning through Landscapes Trust. 
Adams, E. (1991) Back to basics: Aesthetic experience. Children's Environments Quarterly 8 (2), 19-29.

Adams, E. (1993) School's out!: New initiatives for British school grounds. Children's Environments 10 (2), 180-91.

Alexander, J., Wales North, M. and Hendren, M.D.K. (1995) Master gardener classroom garden project: An evaluation of the benefits to children. Children's Environments 12 (2), 256-63.

Ballantyne, R. and Packer, J. (2002) Nature-based excursions: School students' perceptions of learning in natural environments. International Journal of Geographical and Environmental Education 11 (3), 218-36.

Barker, S., Slingsby, D. and Tilling, S. (2003) Teaching Biology Outside the Classroom: Is it Heading for Extinction? FSC Occasional Publication 72. Shrewsbury: Field Studies Council/ British Ecological Society.

Bell, A.C. (2001a) Engaging spaces: On school-based habitat restoration. Canadian Journal of Environmental Education 6, 209-24.

Bell, A.C. (2001b) The pedagogical potential of school grounds. In T. Grant and G. Littlejohn (eds) Greening School Grounds: Creating Habitats for Learning (pp. 9-11). Gabriola Island, BC: New Society.

Canaris, I. (1995) Growing foods for growing minds: Integrating gardening and nutrition education into the total curriculum. Children's Environments 12 (2), 264-70.

Centre for Ecoliteracy (1999) The edible schoolyard. Berkeley, CA: Learning in the Real World.

Cheskey, E. (1994, September/October) Habitat restoration: Changing the schoolyard changes behaviour. FWTAO Newsletter, 2-7.

Comishan, K., Dyment, J.E., Potter, T. and Russell, C.L. (2004) The development and implementation of outdoor-based secondary school integrated programs. Applied Environmental Education and Communication 3 (1), 47-54.

Cronin-Jones, L. (2000) The effectiveness of schoolyards as sites for elementary science instruction. School Science and Mathematics 100 (4), 203-11.

Department of Education and Skills (2003) Growing Schools Garden: Teachers' Resource Pack. United Kingdom: Department of Education and Skills, Learning Through Landscapes, The Federation of City Farms and Community Gardens.

Dyment, J.E. (2004a) 'At that age, you just accept what you have ... You never question things': A case study of student participation in school ground greening projects. Children, Youth and Environments 14 (1), 130-52. See also on WWW at http: / / cye.colorado.edu.

Dyment, J.E. (2004b) Green(ing) school grounds in the Toronto District School Board: An investigation of potential. Unpublished PhD Thesis, Joint PhD Program through Brock University, Lakehead University, University of Windsor, and University of Western Ontario, Ontario, Canada.

Dyment, J.E. (2005) Gaining ground: The power and potential of green school grounds in the Toronto District School Board. Toronto, Ontario: Evergreen. Available at http:/ / www.evergreen.ca/en/lg/lg-resources.html.

Eden, E.S. (1998) Digging down deep: Educational experiences with the earth in a gardening/ farming context. North American Montessori Teacher's Association Journal 23 (1), 323-32.

Engel, S. (1991) The world is a white blanket: Children write about nature. Children's Environments Quarterly 8 (2), 42-5.

Evans, J. (1995) Conflict and control in the school playground. Changing Education: A Journal for Teachers and Administrators 2 (1/2), 17-22.

Evergreen (2001) Patterns, Plants and Playgrounds: Educational Activities for British Columbia School Grounds. Toronto, ON: Evergreen.

Fisher, J.A. (2001) The demise of fieldwork as an integral part of science education in schools: A victim of cultural change and political pressure. Pedagogy, Culture and Society 9 (1), 75-96.

Gamson Danks, S. (2000) Ecological schoolyards. Landscape Architecture 90 (11), $42-7$. 
Grahn, P., Martensoon, F., Lindblad, B., Nilsoon, P. and Ekman, A. (1997) Ute pa Dagis. Stad and Land, [Outdoor Daycare. City and Country] 145. Hassleholm, Sverige: Norra Skane Offset.

Grant, T. and Littlejohn, G. (eds) (2001) Greening School Grounds: Creating Habitats for Learning. Gabriola Island, BC: New Society.

Ham, S.H. and Sewing, D.R. (1988) Barriers to environmental education. Journal of Environmental Education 19 (2), 17-24.

Hansen-Moller, J. and Taylor, G. (1991) Creative nature interpretation for children. Children's Environments Quarterly 8 (2), 30-37.

Hart, P. and Nolan, K. (1999) A critical analysis of research in environmental education. Studies in Science Education 34, 1-69.

Hart, R. (1997) Children's Participation: The Theory and Practice of Involving Young Citizens in Community Development and Environmental Care. London: Earthscan.

Harvey, M.R. (1989) The relationship between children's experiences with vegetation on school grounds and their environmental attitudes. Journal of Environmental Education 21 (2), 9-15.

Humphries, S. and Rowe, S. (1994) The biggest classroom. In P. Blatchford and S. Sharp (eds) Breaktime and the School: Changing Playground Behaviour (pp. 107-17). London: Routledge.

Hunter, J., Layzell, J. and Rogers, N. (1998) School Landscapes: A Participative Approach to Design. Winchester: Hampshire County Council.

Huttenmoser, M. (1995) Children and their living surroundings: Empirical investigations into the significance of living surroundings for the everyday life and development of children. Children's Environments 12 (4), 403-13.

Kenny, K. (1996) Grounds for Learning: A Celebration of School Site Development in Scotland. Winchester: Learning through Landscapes.

Kirkby, M.A. (1989) Nature as refuge in children's environments. Children's Environments Quarterly 6 (1), 7-12.

Konoshima, H. (1995) Participation of school children in agricultural activities at school farms in Shiga Prefecture. Acta Horticulture 391, 217-22.

Lieberman, G.A. and Hoody, L.L. (1998) Closing the Achievement Gap: Using the Environment as an Integrated Context for Learning. Ponway, CA: Science Wizards.

Mabie, R. and Baker, M. (1996) A comparison of experiential instructional strategies upon the science process skills of urban elementary students. Journal of Agricultural Education $37(2), 1-7$.

Malone, K. and Tranter, P.J. (2003a) Children's environmental learning and the use, design and management of school grounds. Children, Youth and Environments 13 (2), On WWW at http: / / cye.colorado.edu. Accessed 15.02.04.

Malone, K. and Tranter, P.J. (2003b) School grounds as sites for learning: Making the most of environmental opportunities. Environmental Education Research 9 (3), 283-303.

Mannion, G. (2003) Children's participation in school grounds developments: Creating a place for education that promotes social inclusion. International Journal of Inclusive Education 7 (2), 175-92.

Martil-de Castro, W. (1999) Grounding environmental education in the lives of urban students. Pathways: The Ontario Journal of Outdoor Education 11 (2), 15-17.

McCutcheon, N. and Swanson, A. (2001) Tips and tricks for taking kids outside. In T. Grant and G. Littlejohn (eds) Greening School Grounds: Creating Habitats for Learning (pp. 127-9). Gabriola Island, BC: New Society.

Moore, R.C. (1996) Outdoor settings for playing and learning: Designing school grounds to meet the needs of the whole child and whole curriculum. North American Montessori Teacher's Association Journal 21 (3), 97-120.

Moore, R.C. and Wong, H.H. (1997) Natural Learning: The Life History of an Environmental Schoolyard. Berkeley, CA: MIG Communications.

Nabhan, G.P. and Trimble, S. (1994) The Geography of Childhood: Why Children Need Wild Spaces. Boston, MA: Beacon.

Olwig, K.R. (1991) Childhood, artistic creation, and the educated sense of place. Children's Environments Quarterly 8 (2), 4-18. 
Puk, T. and Behm, D. (2003) The diluted curriculum: The role of government in developing ecological literacy as the first imperative in Ontario secondary schools. Canadian Journal of Environmental Education 8, 217-32.

Rahm, J. (2002) Emergent learning opportunities in an inner-city youth gardening program. Journal of Research in Science Teaching 39 (2), 164-84.

Rhydden-Evans, Z. (1993) Math in the School Grounds. Winchester: Learning through Landscapes Trust.

Rickinson, M., Dillon, J., Teamey, K., Morris, M., Choi, M.Y., Sanders, D. et al. (2004) A Review of Research on Outdoor Learning. Slough: National Foundation for Educational Research and King's College London.

Rickinson, M., Sanders, D., Chillman, B., Doyle, P. and Jameson, N. (2003) Grounds for Improvement Secondary Action Research Program: Year 2 Report. Hampshire: Learning Through Landscapes.

Scott, W. and Gough, S. (eds) (2003) Sustainable Development and Learning: Framing the Issues. London: Routledge Falmer.

Scott, W., Reid, A. and Jones, N. (2003) Growing Schools: The Innovation Fund Projects (20022003): An External Evaluation. Bath: Council for Environmental Education and University of Bath.

Shuman, D. and Ham, S.H. (1997) Model of environmental commitment. Journal of Environmental Education 28, 25-32.

Simmons, D. (1998) Using natural settings for environmental education: Perceived benefits and barriers. Journal of Environmental Education 29 (3), 23-31.

Simone, M.F. (2002) Back to the basics: Student achievement and schoolyard naturalization. Unpublished MA thesis, Faculty of Arts and Science, Trent University, Peterborough, Ontario.

Thomson, G. and Arlidge, S. (2000) Five-minute Field Trips: Teaching about Nature in your Schoolyard. Calgary, Alberta: Global Environmental and Outdoor Education Council of the Alberta Teacher's Association and the Calgary Zoo.

Titman, W. (1994) Special Places, Special People: The Hidden Curriculum of Schoolgrounds. Surrey: World Wildlife Fund, UK.

Titman, W. (1999) Grounds for Concern: A Report on Secondary School Grounds. Winchester: Learning Through Landscapes.

Toronto District School Board (2004) Ecoschools: School Ground Greening Designing for Shade and Energy Conservation. Toronto, Ontario: Toronto District School Board. 